\title{
逆最適制御に基づく 3 次元空間上での飛行意図の推定*1 Inference of Flight Intent in Three-Dimensional Space Based on Inverse Optimal Control
}

\author{
阿 河 菜々花*3 . 横 山信 宏*2,*3 \\ Nanaka AGA and Nobuhiro YokOYAMA
}

Key Words : Aircraft Traffic Management, Flight Intent, Inference, Conflict Resolution

\begin{abstract}
In order to cope with the rapid increase in global air traffic volume, it is necessary to significantly upgrade the technologies for conflict detection and resolution (CDR). For improving the accuracy of the trajectory prediction that is critical to CDR, we propose a method for flight intent inference of aircraft, which is an extension of the existing method to the flight in three-dimensional space. By solving the inverse problem of optimal control based on three-dimensional trajectory of aircraft, the method infers the flight intent of the aircraft including that of horizontal and/or vertical conflict resolution. The effectiveness of the method as well as the feasibility in real-time applications is demonstrated through numerical examples.
\end{abstract}

\section{1. は じめ に}

世界的な航空交通量の増加傾向は今後も続くと予想され ており，それを見据えて，CNS/ATM (Communication， Navigation, Surveillance/Air Traffic Management) を高 度化する計画が米国・欧州・日本等において展開されてい る1 3). これらの計画においては, 航空機間の経路干渉の検 出・回避技術の高度化が, 重要な技術課題としてとらえら れている。

航空機の経路干渉検出・回避の手法はこれまで幾つも提 案されているが4), その有効性を高めるには一般的に，高 い精度で他機の軌道を予測することが必要とされる．例え ば，軌道予測の精度を高めるために，ADS-B（Automatic Dependent Surveillance Broadcast) を拡張して, ウェイ ポイント (以下，WP と略記する）の位置や通過時刻など の 4 次元飛行計画をブロードキャストするシステムを検討 している研究もある ${ }^{5,6)}$. しかし, 周囲の航空機の飛行計画 の情報が利用可能であっても, その妥当性を確認し7), 軌道 の背後にある意図を推定すること6,8 12) は重要である. そ こで本研究では, 経路干渉の検出・回避のための軌道予測 に適用可能な, 既存の 2 次元空間での飛行意図推定法 ${ }^{12)} に$ ついて, 3 次元空間への拡張を試みる.

本研究では，航空機がほとんどの飛行状況において何ら かの目的を満たすよう，準最適に制御されると仮定する。そ の上で，ターゲット (推定対象) 機の準最適な制御入力と

\footnotetext{
*1 C 2018 日本航空宇宙学会

平成 29 年 11 月 21 日, 第 55 回飛行機シンポジウムにて発表

平成 30 年 3 月 6 日原稿受付

*2 連絡先著者 (Corresponding author): yoko@nda.ac.jp

*3 防衛大学校
}

それに対応する状態軌道を用いて, 最適制御の逆問題13) を 解くことで，未知の目的関数を推定し，寄与度の高い飛行 意図を求める，飛行意図には，座標が既知の WP への移動, 他機との水平方向 - 垂直方向の干渉回避，各種状態の保持 などが含まれる，具体的には，目的関数を，各飛行意図に よって近似的に最小化される量の重み付きの和として表現 し, それぞれの重みを, 対応する飛行意図の寄与度として 解釈する。これらの各重みは，各サンプリング周期におい て実時間で計算される。また， 3 次元空間への拡張に際し て，実際の飛行との対応付けを容易にすべく，水平面内，鉛 直面内の飛行に関する意図をそれぞれ別々に定義する。 な お，航空機の意図の推定に関する先行研究 $6,8 \sim 12)$ では，著 者らによる研究 ${ }^{12)}$ を除き，いずれも他機との干渉回避に関 する明確な定式化がなされていないのに対し，ここでの手 法は水平方向・鉛直方向の干渉回避の意図を明示的に推定 できるという特長を有する.

以降, 本稿では, 2 節で意図推定問題の定式化について 説明する. 次に，3 節において，数值シミュレーションに よる意図推定の具体的な例を通じて，この手法の有効性お よび実時間での適用性を示す。そして 4 節で，結論と今後 の研究課題について述べる.

\section{2. 意図推定問題の定式化}

2.1 運動モデル 本稿においては，簡単のため風の影 響は考慮しないものとする. 3 次元空間における質点とし ての航空機の状態方程式は次式で与えられる. 


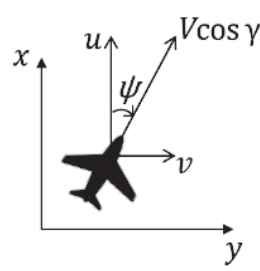

(a) $x-y$ 平面

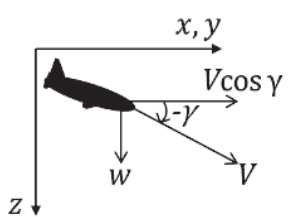

(b) $z-x y$ 平面

第 1 図 慣性座標系に扔ける速度の 3 軸成分と各変数の関係

$$
\left[\begin{array}{c}
\dot{x} \\
\dot{y} \\
\dot{z} \\
\dot{V} \\
\dot{\gamma} \\
\dot{\psi}
\end{array}\right]=\left[\begin{array}{c}
V \cos \gamma \cos \psi \\
V \cos \gamma \sin \psi \\
-V \sin \gamma \\
(T \cos \alpha-D) / m-g \sin \gamma \\
(L+T \sin \alpha) \cos \sigma /(m V)-g \cos \gamma / V \\
(L+T \sin \alpha) \sin \sigma /(m V \cos \gamma)
\end{array}\right]
$$

ここで, $(x, y, z)$ は位置座標, $V$ は速度, $\gamma$ は経路角, $\psi$ は方位角, $T$ は推力, $L$ は揚力, $D$ は抗力, $\alpha$ は迎角, $\sigma$ はバンク角, $m$ は機体質量, $g$ は重力加速度である. また, 慣性座標系における速度の 3 軸方向成分をそれぞれ $u, v, w$ と定義する（第 1 図参照）と, 次の関係式が成り立つ.

$$
\begin{aligned}
& u=V \cos \gamma \cos \psi \\
& v=V \cos \gamma \sin \psi \\
& w=-V \sin \gamma
\end{aligned}
$$

また，(1) 式右辺の第 4〜6 要素に関して, 以下のように定 義する.

$$
\begin{aligned}
& a:=\frac{T \cos \alpha-D}{m}-g \sin \gamma \\
& \eta:=\frac{L+T \sin \alpha}{m V} \cos \sigma-\frac{g}{V} \cos \gamma \\
& \omega:=\frac{(L+T \sin \alpha) \sin \sigma}{m V \cos \gamma}
\end{aligned}
$$

これを (1) 式に代入し，さらに旋回率 $\omega$ に関する微分方程 式 $\dot{\omega}=\chi$ を含めると, 状態方程式は次のように表せる.

$$
\left[\begin{array}{c}
\dot{x} \\
\dot{y} \\
\dot{z} \\
\dot{V} \\
\dot{\gamma} \\
\dot{\psi} \\
\dot{\omega}
\end{array}\right]=\left[\begin{array}{c}
V \cos \gamma \cos \psi \\
V \cos \gamma \sin \psi \\
-V \sin \gamma \\
a \\
\eta \\
\omega \\
\chi
\end{array}\right]
$$

(3) 式はターゲット機固有の運動特性 $(T, L, D$ の特性 および $m$ ) に依存しないため, それらが不明であっても利 用可能である。そこで, 本研究では運動モデルとして (3) 式を用いる。
2.2 飛行意図のモデル化 上で述べた運動モデルの変 数に基づき, 航空機の各種飛行意図に対応する目的関数を, 以下の $(\mathrm{a}) \sim(\mathrm{h})$ のようにモデル化する. ただし, 意図推定 に用いる軌道の時間領域は $\left[t_{0}, t_{\mathrm{f}}\right]$ とする.

(a) 速度保持:

$$
\int_{t_{0}}^{t_{\mathrm{f}}} \dot{V}^{2} d t=\int_{t_{0}}^{t_{\mathrm{f}}} a^{2} d t \rightarrow \operatorname{minimize}
$$

(b) 経路角保持：

$$
\int_{t_{0}}^{t_{\mathrm{f}}} \dot{\gamma}^{2} d t=\int_{t_{0}}^{t_{\mathrm{f}}} \eta^{2} d t \rightarrow \operatorname{minimize}
$$

(c) 方位角保持 :

$$
\int_{t_{0}}^{t_{\mathrm{f}}} \dot{\psi}^{2} d t=\int_{t_{0}}^{t_{\mathrm{f}}} \omega^{2} d t \rightarrow \operatorname{minimize}
$$

(d) 旋回率保持:

$$
\int_{t_{0}}^{t_{\mathrm{f}}} \dot{\omega}^{2} d t=\int_{t_{0}}^{t_{\mathrm{f}}} \chi^{2} d t \rightarrow \operatorname{minimize}
$$

(e) 既知の WP $\left[\begin{array}{lll}x_{w} & y_{w} & z_{w}\end{array}\right]^{T}$ への移動:

まず水平面内においては，機体の方位角 $\psi(t)$ を水平面 内におけるWP の目視角

$$
\mu_{w}(t):=\tan ^{-1}\left(\frac{y_{w}-y}{x_{w}-x}\right)
$$

に対して，終端時刻 $t_{\mathrm{f}}$ でできるだけ近づけることに相当す るので，次のように表せる.

$$
-\cos \left(\mu_{w}\left(t_{\mathrm{f}}\right)-\psi\left(t_{\mathrm{f}}\right)\right) \rightarrow \operatorname{minimize}
$$

ただし，実際の軌道においては，必ずしも終端時刻における 機体の位置が完全に最適性の条件を満たすとは限らず，終 端時刻近傍の機体方位角が概ね WP の目視角に近づこうと する傾向が現れるとみなす方が自然であるため, (4) 式の 代わりに忘却係数 $e^{-\beta\left(t_{\mathrm{f}}-t\right)}$ 付きの時間積分である次式で 目的関数を表す。

$$
-\int_{t_{0}}^{t_{\mathrm{f}}} e^{-\beta\left(t_{\mathrm{f}}-t\right)} \cos \left(\mu_{w}(t)-\psi(t)\right) d t \rightarrow \operatorname{minimize}
$$

ここで， $\beta$ は正の定数であり，これを大きくとるほど終端 時刻に近い時刻での方位角の一致度を重視することに対応 する.

また，鉛直面内におけるWP への移動も，機体の経路角 $\gamma(t)$ を鉛直面内に拈ける指定高度の目視角

$$
\lambda_{w}(t):=-\tan ^{-1}\left(\frac{z_{w}-z(t)}{\sqrt{\left(x_{w}-x(t)\right)^{2}+\left(y_{w}-y(t)\right)^{2}}}\right)
$$

に対して，終端時刻 $t_{\mathrm{f}}$ でできるだけ近づけることに相当す るため, 目的関数は次のように表せる. 
$-\int_{t_{0}}^{t_{\mathrm{f}}} e^{-\beta\left(t_{\mathrm{f}}-t\right)} \cos \left(\lambda_{w}(t)-\gamma(t)\right) d t \rightarrow \operatorname{minimize}$

(f) 指定された方位角の達成：

WP 上で機体の方位角が $\psi_{w}$ に指定される場合は，上記 と同じく，次のように目的関数を表す。

$$
-\int_{t_{0}}^{t_{\mathrm{f}}} e^{-\beta\left(t_{\mathrm{f}}-t\right)} \cos \left(\psi_{w}-\psi(t)\right) d t \rightarrow \text { minimize }
$$

(g) 他機との干渉回避（水平方向）:

以下, ターゲット機近傍の $i$ 番目 $(i=1, \cdots, L)$ の他 機に関連する変数には，上付き添え字 $(i)$ を付すものとす る. また， $R$ を水平方向に扔ける機体間の許容間隔とする. 水平面内に扔ける相対速度ベクトルおよび相対位置ベクト ルをそれぞれ次のように表す。

$$
\begin{aligned}
\boldsymbol{w}^{(i)} & =\left[\begin{array}{l}
u \\
v
\end{array}\right]-\left[\begin{array}{l}
u^{(i)} \\
v^{(i)}
\end{array}\right] \\
\boldsymbol{p}^{(i)} & =\left[\begin{array}{l}
x \\
y
\end{array}\right]-\left[\begin{array}{l}
x^{(i)} \\
y^{(i)}
\end{array}\right]
\end{aligned}
$$

他機の位置 $\left[x^{(i)} y^{(i)}\right]^{T}$ を中心とした半径 $R$ の円に，ター ゲット機から引いた接線方向の 2 本の単位ベクトル $\boldsymbol{d}_{+}^{(i)}$, $\boldsymbol{d}_{-}^{(i)}$ のうち, 相対速度の単位方向べクトル $\boldsymbol{w}^{(i)} /\left|\boldsymbol{w}^{(i)}\right|$ に 近い方を $\boldsymbol{d}^{(i)}$ と表す。 ただし, $\left|\boldsymbol{p}^{(i)}\right|<R$ の場合, $\boldsymbol{d}_{+}^{(i)}$, $\boldsymbol{d}_{-}^{(i)}$ として, $\boldsymbol{p}^{(i)}$ と直交する方向の単位ベクトルを選ぶ. $i$ 番目の他機に対する水平方向の干渉回避の意図は, $\boldsymbol{d}^{(i)}$ の 方向に相対速度べクトルの方向を合わせようとすることに 対応しているとみなし，次のように表す.

$$
-\frac{\left[\boldsymbol{d}^{(i)}\right]^{T} \boldsymbol{w}^{(i)}}{\left|\boldsymbol{w}^{(i)}\right|} \rightarrow \text { minimize }
$$

なお， $\boldsymbol{w}^{(i)}$ および $\boldsymbol{d}^{(i)}$ が水平面内において $X$ 軸正方向と なす角度を $\varphi^{(i)}$ 抢よび $\tilde{\varphi}^{(i)}$ として，(8) 式は次のように も表すことができる。

$$
\begin{aligned}
-\frac{\left[\boldsymbol{d}^{(i)}\right]^{T} \boldsymbol{w}^{(i)}}{\left|\boldsymbol{w}^{(i)}\right|} & =-\left[\begin{array}{c}
\cos \varphi^{(i)} \\
\sin \varphi^{(i)}
\end{array}\right]^{T}\left[\begin{array}{l}
\cos \tilde{\varphi}^{(i)} \\
\sin \tilde{\varphi}^{(i)}
\end{array}\right] \\
& =-\cos \left(\tilde{\varphi}^{(i)}-\varphi^{(i)}\right) \\
& \rightarrow \text { minimize }
\end{aligned}
$$

これらの関係を図で表現したものを，第 2 図に示す.

(9) 式に基づき，ここでも忘却係数付き時間積分を用い て目的関数を表す。

$$
\begin{aligned}
& -\int_{t_{0}}^{t_{\mathrm{f}}} e^{-\beta\left(t_{\mathrm{f}}-t\right)} \delta(t) \cos \left[\rho_{\varphi}\left\{\tilde{\varphi}^{(i)}(t)-\varphi^{(i)}(t)\right\}\right] d t \\
& \quad \rightarrow \text { minimize }
\end{aligned}
$$

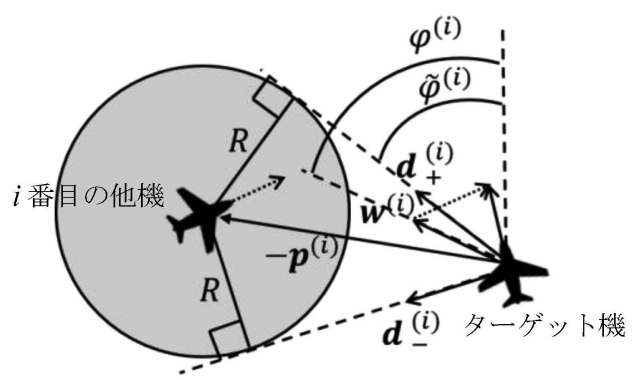

第 2 図 水平面内の干渉回避における幾何学的関係

ただし， $\delta(t)$ は実際に干渉が起きている時刻には 1 ，干渉 が起きていない時刻には 0 となる時変パラメータである. また， $\rho_{\varphi} \in(0,1]$ は定数であり，小さくするほど，理想的 な回避方向と実際の回避方向との差異を小さく評価する効 果を持つ。

(h) 他機との干渉回避（鉛直方向）：

$H$ を鉛直方向における機体間の許容間隔とする.ターゲッ 卜機の位置 $\left[\begin{array}{lll}x y & z\end{array}\right]^{T}$ と他機 $\left[x^{(i)} y^{(i)} z^{(i)}\right]^{T}$ の位置を結ん だ線分を含む鉛直面を以下では基準面と呼ぶ． 3 次元座標 系に扔ける相対位置ベクトルと相対速度べクトルをそれぞ れ以下のように表す。

$$
\left[\begin{array}{l}
x_{r}^{(i)} \\
y_{r}^{(i)} \\
z_{r}^{(i)}
\end{array}\right]=\left[\begin{array}{l}
x-x^{(i)} \\
y-y^{(i)} \\
z-z^{(i)}
\end{array}\right], \quad\left[\begin{array}{c}
u_{r}^{(i)} \\
v_{r}^{(i)} \\
w_{r}^{(i)}
\end{array}\right]=\left[\begin{array}{c}
u-u^{(i)} \\
v-v^{(i)} \\
w-w^{(i)}
\end{array}\right]
$$

また, $D^{(i)}:=\sqrt{\left(x_{r}^{(i)}\right)^{2}+\left(y_{r}^{(i)}\right)^{2}}$ とすると, 相対速度べク トルを基準面に射影して得られるべクトルは, 3 次元表現で

$$
\left[\begin{array}{c}
-\frac{u_{r}^{(i)} x_{r}^{(i)}+v_{r}^{(i)} y_{r}^{(i)}}{D^{(i)}} \cdot \frac{x_{r}^{(i)}}{D^{(i)}} \\
-\frac{u_{r}^{(i)} x_{r}^{(i)}+v_{r}^{(i)} y_{r}^{(i)}}{D^{(i)}} \cdot \frac{y_{r}^{(i)}}{D^{(i)}} \\
w_{r}^{(i)}
\end{array}\right]
$$

となる.これを基準面内の 2 次元べクトルで表現したもの を $\tilde{\boldsymbol{w}}^{(i)}$ とすると，

$$
\tilde{\boldsymbol{w}}^{(i)}=\left[\begin{array}{c}
-\frac{u_{r}^{(i)} x_{r}^{(i)}+v_{r}^{(i)} y_{r}^{(i)}}{D^{(i)}} \\
w_{r}^{(i)}
\end{array}\right]
$$

となる，ただし，第 1 要素は水平方向成分（ターゲット機 から他機に向かう方向を正とする）を，第 2 要素は鉛直方 向成分（下向きを正とする）を表す。基準面に扔ける相対 速度が水平面に対してなす角度（相対経路角と呼び，上向 きを正とする）を次のように表しておく。

$$
\zeta^{(i)}=\tan ^{-1}\left[\frac{-w_{r}^{(i)}}{-\left(u_{r}^{(i)} x_{r}^{(i)}+v_{r}^{(i)} y_{r}^{(i)}\right) / D^{(i)}}\right]
$$

また，基準面内において，他機の現在位置を中心とした，幅 $2 R$, 高さ $2 H$ の長方形（許容領域に対応）の頂点を, ター 


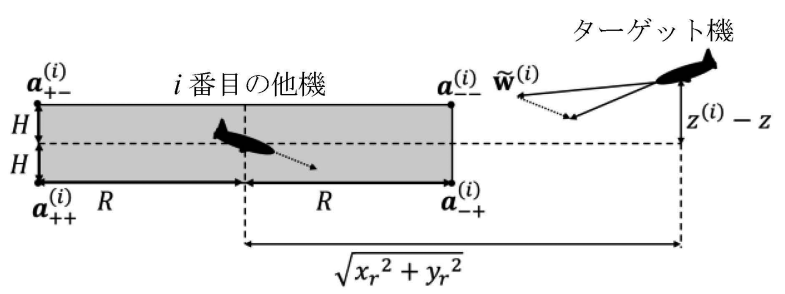

第 3 図 鉛直面内の干渉回避に打ける幾何学的関係

ゲット機の現在位置を原点とした 2 次元ベクトルで表現し たものを次のように表す.

$$
\begin{array}{ll}
\boldsymbol{a}_{++}^{(i)}=\left[\begin{array}{c}
R+D^{(i)} \\
H-z_{r}^{(i)}
\end{array}\right], & \boldsymbol{a}_{+-}^{(i)}=\left[\begin{array}{c}
R+D^{(i)} \\
-H-z_{r}^{(i)}
\end{array}\right] \\
\boldsymbol{a}_{-+}^{(i)}=\left[\begin{array}{c}
-R+D^{(i)} \\
H-z_{r}^{(i)}
\end{array}\right], & \boldsymbol{a}_{--}^{(i)}=\left[\begin{array}{c}
-R+D^{(i)} \\
-H-z_{r}^{(i)}
\end{array}\right]
\end{array}
$$

ただし， $\tilde{\boldsymbol{w}}^{(i)}$ と同様に，これらの 2 次元ベクトルの第 1 要 素は水平方向成分を，第 2 要素は鉛直方向成分を表す。こ れらの関係を図で表現したものを，第 3 図に示す。

ターゲット機から各頂点に向かうベクトルの相対経路角 を次のように表す。

$$
\begin{aligned}
& \tilde{\zeta}_{++}^{(i)}=-\tan ^{-1}\left(\frac{H-z_{r}^{(i)}}{R+D^{(i)}}\right) \\
& \tilde{\zeta}_{+-}^{(i)}=-\tan ^{-1}\left(\frac{-H-z_{r}^{(i)}}{R+D^{(i)}}\right) \\
& \tilde{\zeta}_{-+}^{(i)}=-\tan ^{-1}\left(\frac{H-z_{r}^{(i)}}{-R+D^{(i)}}\right) \\
& \tilde{\zeta}_{--}^{(i)}=-\tan ^{-1}\left(\frac{-H-z_{r}^{(i)}}{-R+D^{(i)}}\right)
\end{aligned}
$$

その上で，鉛直方向の干渉回避の意図は， $\zeta^{(i)}$ を次に示す 望ましい相対経路角 $\tilde{\zeta}^{(i)}$ に合わせようとすることに対応す るものとする.

i) $D_{r}^{(i)}>R$ の場合

$$
\tilde{\zeta}^{(i)}= \begin{cases}\arg \min _{p \in\left\{\tilde{\zeta}_{-+}^{(i)}, \tilde{\zeta}_{+-}^{(i)}\right\}}\left|\zeta^{(i)}-p\right|, & \text { if } z_{r}^{(i)}<-H \\ \arg \min _{p \in\left\{\tilde{\zeta}_{-+}^{(i)}, \tilde{\zeta}_{--}^{(i)}\right\}}\left|\zeta^{(i)}-p\right|, & \text { if }\left|z_{r}^{(i)}\right| \leq H \\ \arg \min _{p \in\left\{\tilde{\zeta}_{++}^{(i)}, \tilde{\zeta}_{--}^{(i)}\right\}}\left|\zeta^{(i)}-p\right|, & \text { if } H<z_{r}^{(i)}\end{cases}
$$

ii) $D_{r}^{(i)} \leq R$ の場合

$$
\tilde{\zeta}^{(i)}= \begin{cases}\tilde{\zeta}_{+-}^{(i)}, & \text { if } z_{r}^{(i)}<-H \\ \pi / 2, & \text { if }-H \leq z_{r}^{(i)}<0 \\ -\pi / 2, & \text { if } 0 \leq z_{r}^{(i)} \leq H \\ \tilde{\zeta}_{++}^{(i)}, & \text { if } H<z_{r}^{(i)}\end{cases}
$$

以上により，鉛直方向の干渉回避の意図は，

$$
-\cos \left(\tilde{\zeta}^{(i)}-\zeta^{(i)}\right) \rightarrow \operatorname{minimize}
$$

と表すことができる。ここでも，水平方向の回避の場合と 同様に，忘却係数 $e^{-\beta\left(t_{\mathrm{f}}-t\right)}$ ，干渉の有無を表す時変パラ メー夕 $\delta(t)$, および定数 $\rho_{\zeta} \in(0,1]$ を用いて, 目的関数 を次のように表す。

$$
\begin{aligned}
& -\int_{t_{0}}^{t_{\mathrm{f}}} e^{-\beta\left(t_{\mathrm{f}}-t\right)} \delta(t) \cos \left[\rho_{\zeta}\left\{\tilde{\zeta}^{(i)}(t)-\zeta^{(i)}(t)\right\}\right] d t \\
& \quad \rightarrow \text { minimize }
\end{aligned}
$$

2.3 目的関数と解くべき最適化問題 システムを離散 時間系に変換し，初期時刻を $t_{0}=M \Delta t$, 終端時刻を $t_{\mathrm{f}}=N \Delta t$ とおくと，上述の各飛行意図をすべて考慮した 最適制御問題の目的関数は，次のように表すことができる。

$$
\begin{aligned}
J= & -\sum_{k=M+1}^{N} \sum_{j=1}^{N_{w}} e^{-\beta \Delta t(N-k)}\left[q_{\mu}^{(j)} \cos \left(\mu_{w k}^{(i)}-\psi_{k}\right)\right] \\
& -\sum_{k=M+1}^{N} \sum_{j=1}^{N_{w}} e^{-\beta \Delta t(N-k)}\left[q_{\psi}^{(j)} \cos \left(\psi_{w k}^{(i)}-\psi_{k}\right)\right] \\
& -\sum_{k=M+1}^{N} \sum_{j=1}^{N_{w}} e^{-\beta \Delta t(N-k)}\left[q_{\lambda}^{(j)} \cos \left(\lambda_{w k}^{(i)}-\lambda_{k}\right)\right] \\
& -\sum_{k=M+1}^{N} \sum_{i=1}^{L} e^{-\beta \Delta t(N-k)} \delta_{k}\left[s_{\varphi}^{(i)} \cos \left\{\rho_{\varphi}\left(\tilde{\varphi}_{k}^{(i)}-\varphi_{k}^{(i)}\right)\right\}\right] \\
& -\sum_{k=M+1}^{N} \sum_{i=1}^{L} e^{-\beta \Delta t(N-k)} \delta_{k}\left[s_{\zeta}^{(i)} \cos \left\{\rho_{\zeta}\left(\tilde{\zeta}_{k}^{(i)}-\zeta_{k}^{(i)}\right)\right\}\right] \\
& +\sum_{k=M+1}^{N} r_{\omega} \omega_{k}^{2}+\sum_{k=M}^{N}\left(r_{a} a_{k}^{2}+r_{\eta} \eta_{k}^{2}+r_{\chi} \chi_{k}^{2}\right)
\end{aligned}
$$

ただ $, q_{\mu}^{(j)}, q_{\psi}^{(j)}, q_{\lambda}^{(j)}, s_{\varphi}^{(i)}, s_{\zeta}^{(i)}, r_{\omega}, r_{a}, r_{\eta}, r_{\chi}$ は各飛行意図 に対応する重みを表し， $j$ 番目 $\left(j=1, \cdots, N_{w}\right)$ の WP に関連する変数には，上付き添え字 $(j)$ を付している。ま た，状態方程式として，離散時間系における以下の近似式 を適用する。

$$
\begin{aligned}
\boldsymbol{F}_{k}:= & \boldsymbol{x}_{k}-\boldsymbol{x}_{k-1} \\
& -\frac{\Delta t}{2}\left[\boldsymbol{f}\left(\boldsymbol{x}_{k}, \boldsymbol{u}_{k}\right)+\boldsymbol{f}\left(\boldsymbol{x}_{k-1}, \boldsymbol{u}_{k-1}\right)\right] \\
= & \mathbf{0}, \\
k= & M+1, \cdots, N \\
\boldsymbol{F}_{M}:= & {\left[\begin{array}{c}
x_{M}-\tilde{x}_{M} \\
y_{M}-\tilde{y}_{M} \\
z_{M}-\tilde{z}_{M} \\
V_{M}-\tilde{V}_{M} \\
\gamma_{M}-\tilde{\gamma}_{M} \\
\psi_{M}-\tilde{\psi}_{M} \\
\omega_{M}-\tilde{\omega}_{M}
\end{array}\right]=\mathbf{0} }
\end{aligned}
$$

ただし， $\boldsymbol{x}_{k}, \boldsymbol{u}_{k}, \boldsymbol{f}$ の定義は以下のとおりである. 
$\boldsymbol{x}_{k}:=\left[\begin{array}{c}x_{k} \\ y_{k} \\ z_{k} \\ V_{k} \\ \gamma_{k} \\ \psi_{k} \\ \omega_{k}\end{array}\right], \quad \boldsymbol{u}_{k}:=\left[\begin{array}{c}\eta_{k} \\ a_{k} \\ \chi_{k}\end{array}\right]$

$\boldsymbol{f}\left(\boldsymbol{x}_{k}, \boldsymbol{u}_{k}\right):=\left[\begin{array}{c}V_{k} \cos \gamma_{k} \cos \psi_{k} \\ V_{k} \cos \gamma_{k} \sin \psi_{k} \\ V_{k} \sin \gamma_{k} \\ a_{k} \\ \eta_{k} \\ \omega_{k} \\ \chi_{k}\end{array}\right]$

また，等式 $\boldsymbol{F}_{M}=\mathbf{0}$ は初期条件であり，チルダ付きの記 号は初期時刻 $t_{0}=M \Delta t$ における真の值を表す.

この最適化問題に対応する Lagrange 関数 $\hat{L}$ は次式で表 される。

$$
\hat{L}=J-\sum_{k=M}^{N} \boldsymbol{\nu}_{k}^{T} \boldsymbol{F}_{k}
$$

ここで, $\nu_{k} \in \mathbb{R}^{7}(k=M+1, \cdots, N)$ は状態方程式に対 する Lagrange 乗数べクトルであり， $\nu_{M} \in \mathbb{R}^{7}$ は初期条件 に対応する Lagrange 乗数べクトルである.この最適化問 題に扮ける最適性の十分条件は, $\hat{L}$ を用いて

$$
\begin{aligned}
& \nabla \hat{L}=\mathbf{0} \\
& \boldsymbol{Z}^{T} \nabla^{2} \hat{L} \boldsymbol{Z} \succ \mathbf{0}
\end{aligned}
$$

および $\boldsymbol{F}_{k}=\mathbf{0}, k=M, \cdots, N$ で表される。ただし， $\nabla$

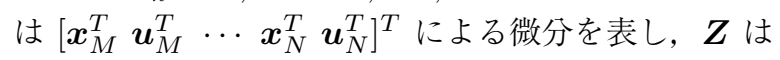

$$
\left[\nabla \boldsymbol{F}_{M} \nabla \boldsymbol{F}_{M+1} \nabla \boldsymbol{F}_{M+2} \cdots \nabla \boldsymbol{F}_{N}\right]
$$

の零空間の基底べクトルを並べた行列を表すままた，(16) 式は左辺の行列が正定であることを意味する。ここでは $\boldsymbol{Z}$ として, $\nabla^{2} \hat{L}$ の有する $(N-M+1)$ 個のブロック対角構 造が $\boldsymbol{Z}^{T} \nabla^{2} \hat{L} \boldsymbol{Z}$ に扔いても保持されるような行列を近似的 に与えるものとする（近似的とは, 厳密には零空間の基底 ベクトルではないことを意味する)。このようにして得られ るブロック対角行列を次のように表す。

$$
\begin{gathered}
\boldsymbol{Z}^{T} \nabla^{2} \hat{L} \boldsymbol{Z}=\left[\begin{array}{cccc}
H_{1} & 0 & \cdots & 0 \\
0 & H_{2} & \ddots & \vdots \\
\vdots & \ddots & \ddots & 0 \\
0 & \cdots & 0 & H_{N-M+1}
\end{array}\right] \\
H_{k}=\left[\begin{array}{ccc}
h_{k, 11} & h_{k, 12} & h_{k, 13} \\
h_{k, 21} & h_{k, 22} & h_{k, 23} \\
h_{k, 31} & h_{k, 32} & h_{k, 33}
\end{array}\right] \\
k=1, \cdots, N-M+1
\end{gathered}
$$

以上の準備のもと，意図推定のための逆最適制御問題に おいては，観測ないし推定された状態変数・制御入力の時

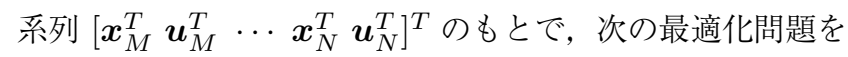
解 $<$.

$$
\begin{aligned}
& \underset{\boldsymbol{\rho}_{N}, \boldsymbol{\nu}_{M}, \cdots, \boldsymbol{\nu}_{N}}{\operatorname{minimize}}: \\
& \quad(\nabla \hat{L})^{T} \nabla \hat{L}+\sigma\left(\boldsymbol{\rho}_{N}-\boldsymbol{\rho}_{N-1}\right)^{T}\left(\boldsymbol{\rho}_{N}-\boldsymbol{\rho}_{N-1}\right) \\
& h_{k, i i}-\sum_{j=1, j \neq i}^{3}\left|h_{k, i j}\right| \geq \varepsilon, \\
& \quad i=1,2,3, \quad k=1, \cdots, N-M+1 \\
& \sum_{i=1}^{N_{w}}\left(q_{\mu}^{(i)}+q_{\psi}^{(i)}\right)+\sum_{i=1}^{L} s_{\varphi}^{(i)}=1 \\
& \sum_{i=1}^{N_{L}} q_{\lambda}^{(i)}+\sum_{i=1}^{L} s_{\zeta}^{(i)}=1 \\
& \sum_{i=1}^{L}\left(s_{\varphi}^{(i)}+s_{\zeta}^{(i)}\right) \leq 1
\end{aligned}
$$

ただし， $\sigma$ は正の定数， $\varepsilon$ は正の微小な定数， $\rho_{N}$ は重 みをまとめたべクトルであり， $\rho_{N-1}$ は意図推定の前のス テップに扔いて求めた既知の重みベクトルを表す．(19) 式 は, (16) 式の十分条件に対応する式である. 元の最適制御 問題における $\boldsymbol{F}_{k}=\mathbf{0}, k=M, \cdots, N$ は，与えられた $\left[\begin{array}{lllll}\boldsymbol{x}_{M}^{T} & \boldsymbol{u}_{M}^{T} & \cdots & \boldsymbol{x}_{N}^{T} & \boldsymbol{u}_{N}^{T}\end{array}\right]^{T}$ に扔いて近似的に満たされる上 に, $\boldsymbol{\rho}_{N}, \boldsymbol{\nu}_{M}, \cdots, \boldsymbol{\nu}_{N}$ とは無関倸であるため, この逆最適 制御問題には含まれない，また，ここでは，水平方向およ び鉛直方向の運動のそれぞれに意図の自由度があるものと し，(20) 式，(21) 式のように独立に重みを正規化している ことに注意されたい.

\section{3. 数值シミュレーション}

提案した手法の有効性を検証するため，ここでは 4 つの ケースに扮ける数值シミュレーション例を示す（それぞれ ケース 1，2，3，4 と呼ぶ)。すべてのケースについて，2機 の航空機の 3 次元空間に扔ける軌道から, 水平方向 ·鉛直 方向それぞれに関して，WP へ向かう意図と他機との干涉 を避ける意図の重みを算出し，その時間履歴を求めた。推 定に用いる軌道は各サンプリング時刻から 10 秒間遡った時 点までの軌道とし $(N-M=10)$, 意図推定のサンプリン グ周期は 1 秒とした。また，シミュレーション開始直後の 10 秒間に抒いては，データ数が足りないため意図推定を行 わないものとした.

各ケースの軌道を第 4 図から第 7 図の (a)に, それら の軌道に基づいて推定された飛行意図の重みを第 4 図か ら第 7 図の (b) にそれぞれ示す。それぞれの図の (a) に 扔いては, 3 次元空間に打ける軌道を $z=0$ の水平面上 に投影した場合の軌道についても描いている，また，各図 の (a)には 2 機が最も接近した点 (CPA：Closest Point of Approach) を示して抢り, ここでは, CPA 間の水平 


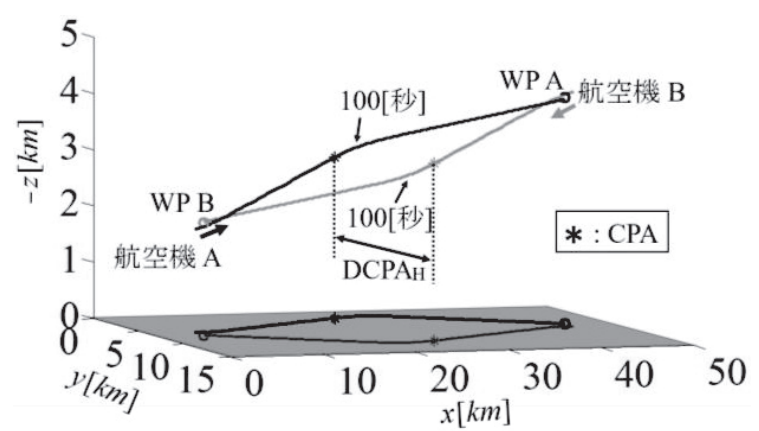

(a) 軌道

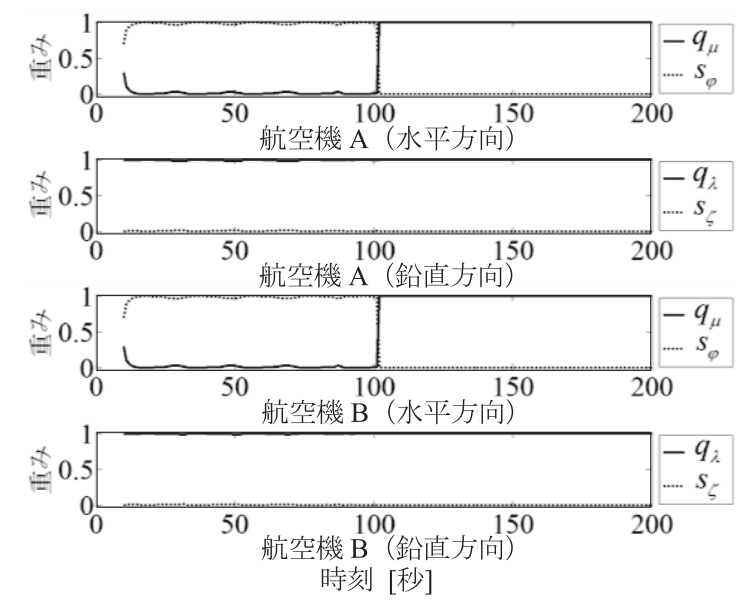

(b) 重みの時間履歴

第 4 図 ケース 1 (2 機とも水平方向に回避 $)$

方向および鉛直方向の距離を，それぞれ $\mathrm{DCPA}_{\mathrm{H}}$ および $\mathrm{DCPA}_{\mathrm{V}}$ と表すこととする．水平方向，鉛直方向に打ける 許容間隔は，それぞれ $R=9.26[\mathrm{~km}], H=0.305[\mathrm{~km}]$ に 設定して扔り, 干渉の回避は, $\mathrm{DCPA}_{\mathrm{H}} \geq 9.26[\mathrm{~km}]$ ある いは $\mathrm{DCPA}_{\mathrm{V}} \geq 0.305[\mathrm{~km}]$ を軌道全域で達成するために 行われる.

第 4 図 (a) に示すケース 1 の軌道において，2 機の航空 機はそれぞれ水平方向に互いを回避しつつ WP へ向かう. $\mathrm{DCPA}_{\mathrm{H}}$ は $9.21[\mathrm{~km}]$ (スタートから 89 秒後) であり, CPA までは互いを回避するような軌道をとり，CPA を過ぎてか らそれぞれの WP へと方位角を変化させている．第 4 図 (b) に示寸重みの履歴を見ると, 水平方向に関して, 機体 A，B ともにスタートから 100 秒までは干渉回避の重みで ある $s_{\varphi}$ が大きく，それ以降はWP 向かう重みである $q_{\mu}$ が大きくなっている。ここで， $q_{\mu}$ は CPA 通過直後から小 さくなるはずであるが，そうならないのは，意図推定に用 いるのが過去 10 秒の軌道であることによる. このため, 航 空機の意図と軌道が互いを水平方向に避けるものから WP へ向かうものへと変化しても, 数秒間は過去の軌道による $s_{\varphi}$ の重みの方が大きくなっている。このような，実際の 軌道に対して推定される意図が遅れて発生する現象は, 以 降の例にも現れている.一方，鉛直方向の意図については， 干渉回避の意図を表す $s_{\zeta}$ が常に小さいままであり, 互い を水平方向に回避するという飛行の様子と整合している.

第 5 図 (a) に示すケース 2 の軌道において，2 機は互い

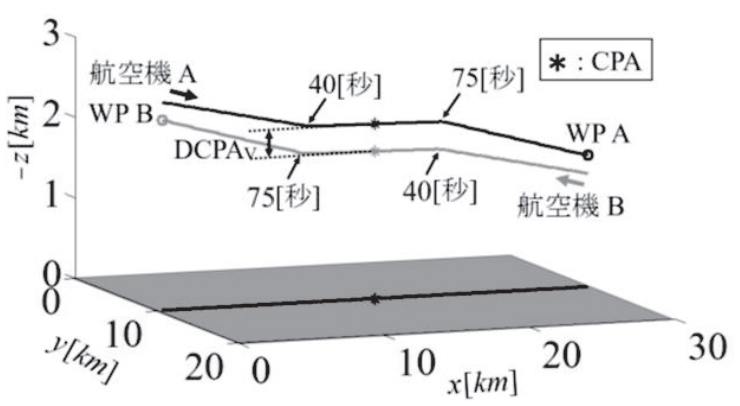

(a) 軌道
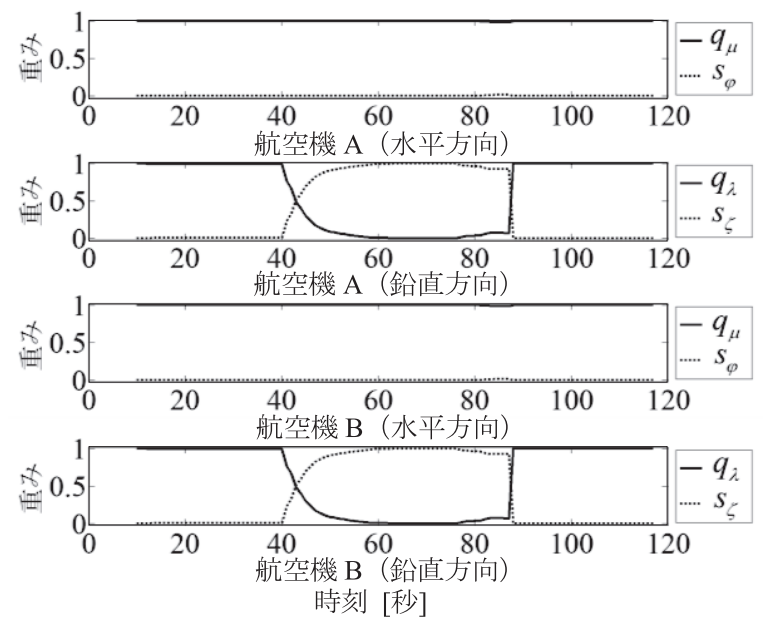

(b) 重みの時間履歴

第 5 図 ケース $2(2$ 機とも同一鉛直面内で飛行し, 鉛直方向に回避 $)$

を鉛直方向に回避しつつ WP へ向かっている. $\mathrm{DCPA}_{\mathrm{V}}$ は $0.339[\mathrm{~km}]$ （スタートから 59 秒後）であり, スタートから 40 秒後までは機体 $\mathrm{A}, \mathrm{B}$ ともに WP へ向かい，その時点か ら 75 秒後あたりまで互いを鉛直方向に避け，それ以降は 再びWPへと向かう。第 5 図 (b) に示す重みの履歴を見る と, 水平方向に関しては, 干渉回避を表す $s_{\varphi}$ が常に小さ いままであり，互いを鉛直方向に回避するという軌道の様 子と整合している．次に鉛直方向の意図に関して，2機と も40秒を超えたあたりから次第に干渉回避を表す $s_{\zeta}$ が増 加していき，50 秒後あたりで完全に支配的になっている. そして 85 秒を過ぎたあたりから再び WP へ向かう重みで ある $q_{\lambda}$ が大きくなる。この意図推定結果は，上述した意 図推定が遅れる傾向を含むが, ケース 2 の軌道に対して概 ね妥当であることがわかる.

第 6 図 (a) に示されるケース 3 の軌道において，2機は 異なる鉛直面内でそれぞれ飛行するが，互いを鉛直方向に 回避しつつ WP へ向かう. DCPAV は $0.356[\mathrm{~km}]$ （スター トから 60 秒後）であり，スタートから 45 秒後あたりまで は機体 A, B ともにWP へ向かい，85 秒後あたりまで互 いを鉛直方向に避け，それ以降は再びWP へと向かう。第 6 図 (b) に示す重みの履歴を見ると, 水平方向に関しては, 干渉回避を表す $s_{\varphi}$ は常に小さいままであり, 互いを鉛直 方向に回避するというケース 3 の軌道の様子と適合してい る. 次に鉛直方向の意図に関して, 2 機とも 45 秒あたりか ら次第に干渉回避を表す $s_{\zeta}$ が増加していき， 70 秒あたり 


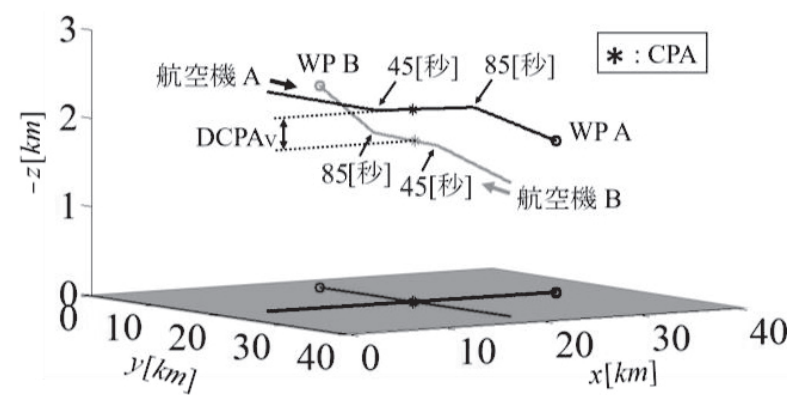

(a) 軌道

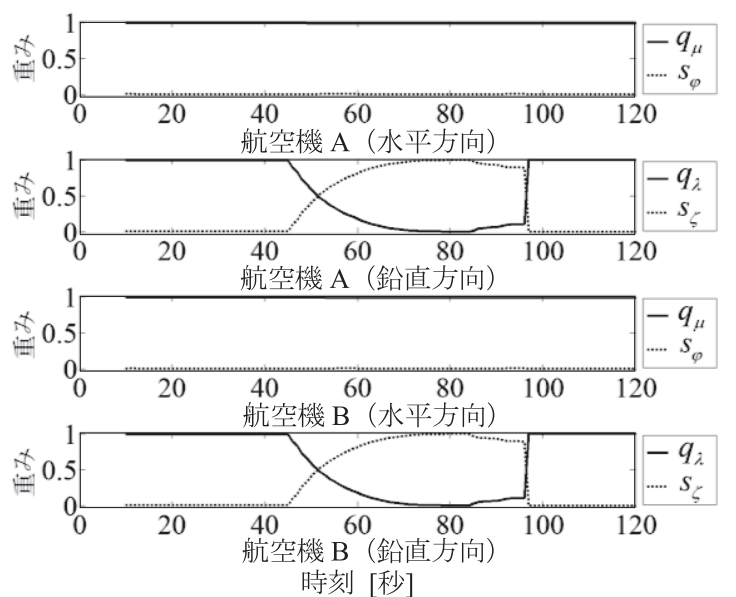

(b) 重みの時間履歴

第 6 図 ケース $3(2$ 機が異なる鉛直面内で飛行し，鉛直方向に回避 $)$

で完全に支配的になっている，そして 95 秒あたりから再び $\mathrm{WP}$ へ向かう重みである $q_{\lambda}$ が大きくなる．この意図推定 結果も，上述した意図推定が遅れる傾向を含むが，ケース 3 の軌道に対して概ね妥当といえる.

第 7 図 (a)に示寸ケース 4 の軌道に打いて，機体 A は機体 $\mathrm{B}$ を避けることなくWPへ向かい，機体 B の みが機体 A を 水平方向に避けながら WP へ向かっている.この軌道は久 タートから 29〜216 秒後までの間, $\mathrm{DCPA}_{\mathrm{V}}$ が $0.305[\mathrm{~km}]$ を下回っており，水平方向の安全間隔が必要となる。機体 B はスタートから機体 $\mathrm{A}$ を水平方向に避けて㧍り，鉛直方向 の安全間隔が保たれていない時刻の間，水平方向の安全間 隔を保つことができている．DCPA トから 216 秒後) である. 第 7 図 (b) に示す重みの履歴を 見ると, 水平方向に関しては, 機体 A の干渉回避を表す $s_{\varphi}$ が常に小さい值をとっており, 回避の意図がないことを軌 道から推定することができている。機体 B に関しては, 意 図推定が始まってから最初の約 10 秒間はWP に向かう方 向から干渉を回避する方向へと方位角を変化させ始めてい るところであるため, WP へ向かう重みである $q_{\mu}$ が大き く出ている. その後干渉回避を表す $s_{\varphi}$ が大きくなり, 安 全間隔を達成してからは, 安全間隔を保ちながらもWP の 方角へと少しずつ近づいているため， $s_{\varphi}$ とともに $q_{\mu}$ がよ り大きな重みとして発生している。 そして拈よそ 170 秒後 からは，完全に $q_{\mu}$ が支配的となっている，上述した意図 推定が遅れる傾向のため, スタートから 225 秒後あたりま

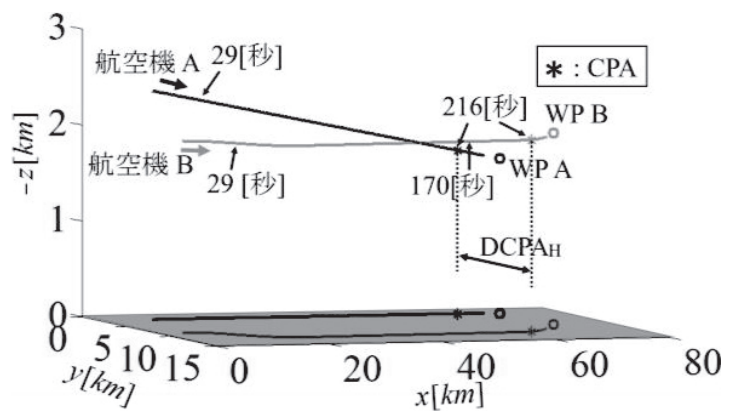

(a) 軌道
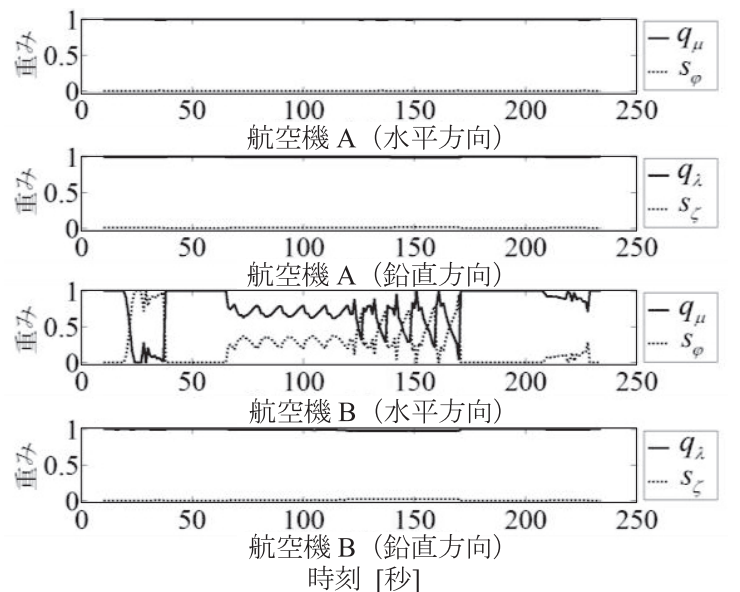

(b) 重みの時間履歴

第 7 図 ケース 4 (機体 $\mathrm{B}$ のみ水平方向に回避)

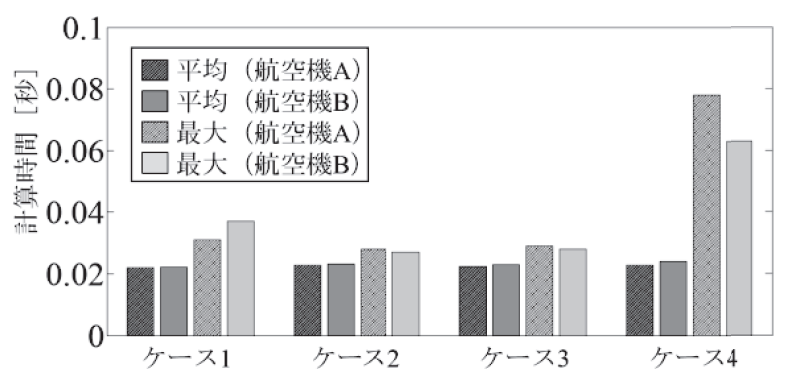

第 8 図 各ケース, 各機体における意図推定に要した計算時間の 最大值・平均值

で，機体 B には $s_{\varphi}$ が 0 とならない区間が見られる。また， 鉛直方向に関しては 2 機とも常に干渉回避を表す $s_{\varphi}$ が小 さいままである，以上の結果より，第 7 図 (b) の重みグラ フは，ケース 4 の軌道に対して概ね妥当であることがわか る.また，各瞬間に扔いて，2機とも，他機に対する自機の 相対的な位置・速度べクトルが対称的な関係であるにもか かわらず，機体 B のみに回避の意図が検出されており，こ れは逆最適制御を利用した本手法の利点であるといえる.

ケース 1〜4の 2 機それぞれについて，1秒ごとに行う意 図推定 1 回にかかった計算時間の，各ケースを通した平均 值と最大值を第 8 図にまとめる。なお，計算には通常のデ スクトップ PC (CPU: Intel ${ }^{\circledR}$ Core $^{\mathrm{TM}}$ i7-6700 $3.40 \mathrm{GHz}$, RAM: $32.0 \mathrm{~GB}$, OS: Windows 1064 bit）を用い，最適化 問題のソルバーとして IBM ${ }^{\circledR}$ ILOG $^{\circledR}{ }^{\circledR}$ CPLEX ${ }^{\circledR} 12.63$ を 
用いた。各ケースの平均值はおよそ 0.02 秒，最大值は遅く ても約 0.06 秒となっており，実用に際して十分な計算速度 を持っていることが確認できる。

\section{4. ま と め}

逆最適制御に基づく航空機の意図推定手法を, 既存の水 平面内のみで定式化されたものから，3 次元空間での定式化 に拡張し，その有効性について確認することができた。今 後の課題として, 定点周りの旋回や特定領域の回避を含む 複雑な飛行経路の考慮, 風の影響の考慮など, よりさまざ まな状況に対応できるよう更に手法を拡張することが挙げ られる。

本研究は，JSPS 科研費 JP15K18289，JP18K04574 の 助成を受けて実施された。

\section{参 考 文 献}

1) Joint Planning and Development Office: Concept of Operations for the Next Generation Air Transportation System Ver. 3.2, 2011.

2) Single European Sky ATM Research Joint Undertaking: European ATM Master Plan Edition 2015, 2015.

3) Ministry of Land, Infrastructure, Transport, and Tourism Study Group for the Future Air Traffic Systems: Long-Term Vision for the Future Air Traffic Systems, 2010.

4) Kuchar, J. K. and Yang, L. C.: A Review of Conflict Detection and Resolution Modeling Methods, IEEE Trans. Intel- ligent Transportation Systems, 1, 4 (2000), pp. 179-189.

5) Barhydt, R. and Warren, A.: Newly Enacted Intent Changes to ADS-B MASPS: Emphasis on Operations, Compatibility, and Integrity, Proceedings of AIAA Guidance, Navigation, and Control Conference, Monterey, CA, 2002, AIAA 20024932 .

6) Hwang, I. and Seah, C. E.: Internet-Based Probabilistic Conflict Detection for the Next Generation Air Transportation System, Proc. IEEE, 96, 12 (2008), pp. 2040-2059.

7) Reynolds, T. and Hansman, R.: Conformance Monitoring Approaches in Current and Future Air Traffic Control Environments, Proceedings of 21st IEEE/AIAA Digital Avionics Systems Conference, Irvine, CA, No. 7C1, 2002.

8) Krozel, J. D. and Andrisani, D.: Intent Inference with Path Prediction, J. Guid. Control Dynam., 29, 2 (2006), pp. 225236

9) Yepes, J. L., Hwang, I. and Rotea, M.: New Algorithms for Aircraft Intent Inference and Trajectory Optimization, J. Guid. Control Dynam., 30, 2 (2007), pp. 370-382.

10) Liu, W. and Hwang, I.: Probabilistic Trajectory Prediction and Conflict Detection for Air Traffic Control, J. Guid. Control Dynam., 34, 6 (2011), pp. 1779-1789.

11) Maeder, U., Morari, M. and Baumgartner, T. I.: Trajectory Prediction for Light Aircraft, J. Guid. Control Dynam., 34, 4 (2011), pp. 1112-1119.

12) Yokoyama, N.: Inference of Aircraft Intent via Inverse Optimal Control Including Second-Order Optimality Condition, J. Guid. Control Dynam., 41, 2 (2018), pp. 349-359.

13) Keshavarz, A., Wang, Y. and Boyd, S.: Imputing a Convex Objective Function, Proceedings of 2011 IEEE International Symposium on Intelligent Control, Denver, CO, 2011, pp. 613-619. 